\title{
Similarities between Plasmids of the P-incompatibility Group Derived from Different Bacterial Genera
}

\author{
By VILMA A. STANISICH* AND J. M. ORTIZ† \\ Department of Bacteriology, Medical School, University of Bristol, Bristol BS8 ITD
}

(Received 8 August 1975 ; revised 8 January 1976)

\begin{abstract}
SUMMARY
The properties of four P-group plasmids, R26, R527, R75I and R906, which differ in resistance phenotype or in the bacterial species in which they were first detected, have been compared with the prototype of this group, RPI. Two of the plasmids, $R_{2} 6$ and $R_{527}$, are new isolates which have been assigned to the $P$ group because of their incompatibility with $\mathrm{R} 75 \mathrm{I}$. The properties studied include response to aeruginocin and to male and female sex-specific phages, interaction with prophage $B_{3}$ and fertility inhibition by plasmid R 38 . Strains harbouring these plasmids behaved similarly in all tests except those involving aeruginocin. This suggests that the locus for aeruginocin-insensitivity is one of the R-determinants whereas the genes controlling the remaining characteristics are closely linked to the transfer factor. These plasmids may therefore have a common ancestor and their differences in resistance phenotype may simply reflect recombination events which they have undergone subsequently. Their similarity is also seen in transduction experiments, since determinants from two of these plasmids can be 'rescued' by the P-group plasmid $\mathrm{RI}_{\mathrm{I}} 8$ if this is already present in the recipient cell and the host recombination system is functional.
\end{abstract}

\section{INTRODUCTION}

The $\mathrm{R}$ plasmid, $\mathrm{RP} 4$, which was first detected in Pseudomonas aeruginosa, is readily transferable to a wide variety of bacterial species and is the prototype of the P-incompatibility group (Datta et al., I97I). This plasmid is probably identical to RPI (Grinsted et al., I972; Holloway \& Richmond, I973) and RI8 (Chandler \& Krishnapillai, I974b; Stanisich, Bennett \& Ortiz, 1976), since all were derived from $P$. aeruginosa 1822 , have the same molecular properties, and confer the same resistance phenotype [carbenicillin $(\mathrm{Cb})$, neomycin/kanamycin $(\mathrm{Nm} / \mathrm{Km})$, tetracycline (Tc)]. Recently, P-group plasmids with different resistance phenotypes have been reported and their geographical distribution seems widespread (Davey \& Pittard, I974; Grant \& Pittard, 1974; Hedges, Jacob \& Smith, I974; Jobanputra \& Datta, I974; Hedges, Rodriguez-Lemoine \& Datta, 1975). The object of the present study was to assess the uniformity of properties among P-group plasmids which, in terms of resistance phenotype or initial carrier strain, differed from those previously described. We have used the plasmids R75I (Jobanputra \& Datta, 1974) and R906 (Hedges et al., 1974) which confer resistance to trimethoprim (Tp) and to ampicillin (Ap), streptomycin $(\mathrm{Sm})$, sulphonamides $(\mathrm{Su})$ and mercuric salts $(\mathrm{Hg})$ respectively, together with two new plasmids, R26 and R527, derived from Serratia and Pseudomonas species isolated in Spain. R26 and R527 are assigned to the P group by their incompatibility with $\mathrm{R}_{75 \mathrm{I}}$; and the properties of the four plasmids, R26, R527, R75I and R906, are then compared with those determined by RPI.

* Present address: Department of Microbiology, La Trobe University, Bundoora 3083, Australia.

$\dagger$ Present address: Departmento de Bioquimica, Facultad de Ciencias, Universidad de Bilbao, Spain. 


\section{Table I. Bacterial strains}

\begin{tabular}{|c|c|c|}
\hline Strain & Genotype & Reference \\
\hline \multicolumn{3}{|l|}{ Escherichia coli $\mathrm{K} \mathrm{I} 2$} \\
\hline UBI30I $=\mathrm{W}_{3} 110$ & rif & Grinsted et al. (1972) \\
\hline $\mathrm{JC} 3272$ & $h i s, l y s, \operatorname{trp}, \operatorname{str} A$ & Achtman et al. (1971) \\
\hline I 85 nal & prototroph, nal & S. Falkow (personal communication) \\
\hline \multicolumn{3}{|l|}{$\begin{array}{l}\text { Pseudomonas } \\
\text { aeruginosa } \mathrm{PAO}\end{array}$} \\
\hline PAO8 & met28, ilv202, strI & Isaac \& Holloway (1968) \\
\hline PAO2OOI & $\arg 32, \operatorname{str} 39, \operatorname{chl} 2$ & Chandler \& Krishnapillai (1974a) \\
\hline $\mathrm{PAO} 2002$ & $\arg 32, \operatorname{str} 39$, chl2, recI & Chandler \& Krishnapillai (1974a) \\
\hline PAO2635 & $\operatorname{trp54}$, rif $_{3}$, fonIoI & This paper \\
\hline PAO2637 & prototroph, chl2, fonIoo & This paper \\
\hline PA09501 & adeI 36, leu $8, \mathrm{chl}_{3}$, rifI & This paper \\
\hline PAO9502 & $\operatorname{adeI} 36, \mathrm{leu} 8, \mathrm{ch}_{3}$, rifi, $\left(\mathrm{B}_{3}\right)$ & This paper \\
\hline
\end{tabular}

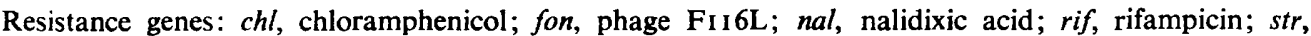
streptomycin. Nutritional requirements: ade, adenine; arg, arginine; $i l v$, isoleucine plus valine; his, histidine; leu, leucine; lys, lysine; met, methionine; trp, tryptophan.

Table 2. Origins and phenotypes of P-group plasmids

\begin{tabular}{|c|c|c|c|c|}
\hline Plasmid & $\begin{array}{l}\text { Resistance } \\
\text { phenotypes }\end{array}$ & $\begin{array}{l}\text { Carrier } \\
\text { strain }\end{array}$ & $\begin{array}{c}\text { Geographical } \\
\text { origin }\end{array}$ & Reference \\
\hline RPI & $\mathrm{Cb} \mathrm{Nm} / \mathrm{Km} \mathrm{Tc}$ & $\begin{array}{l}\text { Pseudomonas } \\
\text { aeruginosa } \text { I } 822\end{array}$ & $\begin{array}{l}\text { U.K. } \\
\text { (Birmingham) }\end{array}$ & Grinsted et al. (1972) \\
\hline R26 & $\mathrm{Cb} \mathrm{Nm} / \mathrm{Km} \mathrm{Tc} \mathrm{Sm} \mathrm{Su} \mathrm{Gm} \mathrm{Hg}$ & $\begin{array}{l}\text { Serratia } \\
\text { marcescens }\end{array}$ & Spain & This paper \\
\hline $\mathrm{R}_{527}$ & $\mathrm{Cb} \mathrm{Nm} / \mathrm{Km} \mathrm{Tc} \mathrm{Sm} \mathrm{Su} \mathrm{Gm} \mathrm{Hg}$ & $\begin{array}{l}\text { Pseudomonas } \\
\text { aeruginosa }\end{array}$ & Spain & This paper \\
\hline R75I & $\mathrm{Tp}$ & $\begin{array}{l}\text { Klebsiella } \\
\text { aerogenes }\end{array}$ & U.K. & Jobanputra \& Datta (I974) \\
\hline RPI & $\mathrm{Ap} \mathrm{Sm} \mathrm{Hg} \mathrm{Su}$ & $\begin{array}{l}\text { Bordetella } \\
\quad \text { bronchiseptica }\end{array}$ & Japan & Hedges et al. (1974) \\
\hline
\end{tabular}

\section{METHODS}

Media. The nutrient agar (NA), nutrient overlay agar for phage propagation, and nutrient broth (NB), were described by Beard, Howe \& Richmond (1972). The compositions of minimal medium (MM) for P. aeruginosa and for Escherichia coli were given by Stanisich \& Holloway (1972) and Grinsted et al. (1972) respectively.

Bacteria. The derivatives of $E$. coli $\mathrm{KI} 2$ and $P$. aeruginosa PAO used in this work are shown in Table I. Plasmid-carrying sub-lines were constructed for some of these strains (see Tables 3 to 7). The aeruginocinogenic strain $P$. aeruginosa 4I (Holloway et al., 1974), provided by B. W. Holloway, Monash University, Australia, was also used.

Plasmids. The origins and resistance phenotypes of the plasmids are shown in Table 2. Escherichia coli $\mathrm{J}_{53}$ and $\mathrm{J53}^{-2}$ carrying $\mathrm{R}_{75 \mathrm{I}}$ and R906 respectively, were provided by N. Datta, Royal Postgraduate Medical School, Hammersmith Hospital, London. Clinical isolates of Serratia marcescens and $P$. aeruginosa carrying $\mathrm{R} 26$ and $\mathrm{R} 527$ respectively, were provided by D. Damaso, Clinica Puerta de Hiero, Madrid, Spain. These plasmids were transferred to JC3272 (provided by A. J. Clark, University of California, Berkeley, U.S.A.) directly or, in the case of R26 and R527, via E. coli I85. RPI was transferred to UBI30 I from $P$. aeruginosa PA08.RPI (Stanisich, 1974b). R9I, its derepressed derivative 
Table 3. Resistance phenotype of $R^{-}$and $R^{+}$lines of $E$. coli $\mathrm{KI} 2$ and $P$. aeruginosa PAO

\begin{tabular}{|c|c|c|c|c|c|c|c|c|}
\hline \multirow[b]{2}{*}{ Strain } & \multicolumn{8}{|c|}{ Minimum inhibitory concentration $\left(\mu \mathrm{g} \mathrm{ml}^{-1}\right)$} \\
\hline & $\mathrm{Cb}$ & $\mathrm{Nm}$ & $\mathrm{Km}$ & $\mathrm{Tc}$ & $\mathrm{Sm}$ & $\mathrm{Gm}$ & $\mathbf{H g}$ & $\mathrm{Su}$ \\
\hline \multicolumn{9}{|l|}{ E. coli $\mathrm{UBI} 30 \mathrm{I}$} \\
\hline $\mathbf{R}^{-}$ & $<3$ & 0.3 & $<3$ & $<3$ & 0.6 & $<0 . \mathrm{I}$ & $<2$ & $<7$ \\
\hline R906 & 30 & 0.3 & $<3$ & $<3$ & 7 & $<0.1$ & $<2$ & 500 \\
\hline RPI & $>2000$ & 30 & 125 & 125 & 0.6 & $<0 \cdot I$ & $<2$ & $<7$ \\
\hline R26, R527 & $>2000$ & 15 & 125 & I 25 & 7 & 10 & 40 & 250 \\
\hline \multicolumn{9}{|c|}{ P. aeruginosa $\mathrm{PAO} 2635$} \\
\hline $\mathbf{R}^{-}$ & 30 & 7 & 30 & 7 & 7 & 0.6 & $<2$ & 15 \\
\hline R906 & 125 & 7 & 30 & 7 & 500 & 0.6 & 40 & 2000 \\
\hline RPI & $>2000$ & 500 & $>1000$ & 500 & 7 & 0.6 & $<2$ & $\mathrm{I}$ \\
\hline R26, R527 & 1000 & 500 & $>1000$ & 500 & 250 & $>40$ & 40 & $<2000$ \\
\hline
\end{tabular}

R9I-2I and $\mathrm{R}_{3} 8$ have been described previously (Stanisich, 1974b). $\mathrm{R}_{38-5}$ is a derivative of R38 which does not inhibit the fertility of RPI. RI8-I8 is a carbenicillin-sensitive derivative of RI 8 (Chandler \& Krishnapillai, I974 b) provided by P. M. Chandler, Monash University, Australia. R I8-9I is a transfer-defective derivative of RI 8-I 8 selected by its hosts' resistance to phage PR4.

Phages. These were the male-specific phages PRRI and PRDI (Olsen \& Thomas, I973; Olsen, Siak \& Gray, 1974) provided by R. H. Olsen, Michigan University, U.S.A., and $\mathrm{PR}_{3}, \mathrm{PR}_{4}$, and Pf3 (Stanisich, I974b), the temperate phages FII6L, GIOI, B3, B33 and B39, and the virulent phage E79 (Krishnapillai, 1974; Holloway \& Krishnapillai, 1975; Morgan \& Stanisich, 1976). The mutant phage GIOI-I was provided by P. M. Chandler.

General methods. Mating experiments, propagation of phages, transduction with FI I6L and spot assays to determine phage titre or efficiency of plating (e.o.p.) were all carried out as previously described (Stanisich, 1974 $a, b$ ). The preparation of aeruginocin by mitomycin $\mathrm{C}$ induction and the determination of its titre was as described by Holloway et al. (1974).

Minimum inhibitory concentration (m.i.c.). The concentration of antibacterial agents inhibitory to bacterial growth was determined by plating single-colony-forming units on to NA containing the agent at appropriate concentrations. For sulphathiazole, lysed horse blood NA was used. The blood was lysed with saponin $(2 \%, v / v)$ then added to molten NA at about $48{ }^{\circ} \mathrm{C}$ to a final concentration of $5 \%(\mathrm{v} / \mathrm{v})$. Sulphathiazole was included as required and the plates stored at $4{ }^{\circ} \mathrm{C}$ for $24 \mathrm{~h}$ prior to use.

\section{RESULTS}

\section{Resistance phenotype}

The m.i.c. of various antibacterial agents to $\mathrm{R}^{-}$and $\mathrm{R}^{+}$lines of $E$. coli $\mathrm{KI} 2$ and $P$. aeruginosa PAO are shown in Table $3 . \mathrm{R}_{2} 6$ and $\mathrm{R}_{527}$ both share with $\mathrm{RPr}$ the resistance pattern $\mathrm{Cb} \mathrm{Nm} / \mathrm{Km} \mathrm{Tc}$, but in addition confer resistance to mercuric ions, streptomycin, sulphathiazole $(\mathrm{Su})$ and gentamicin $(\mathrm{Gm})$. The responses of $\mathrm{R}_{75} \mathrm{I}^{+}$lines were similar to their $\mathrm{R}^{-}$ parents (data not shown) except with trimethoprim. The m.i.c. of this compound to $\mathrm{R}^{-} E$. coli and $P$. aeruginosa was 0.5 and $60 \mu \mathrm{g} \mathrm{ml}^{-1}$ respectively, but to $\mathrm{R} 75 \mathrm{I}^{+}$bacteria it exceeded I $\mathrm{mg} \mathrm{ml}^{-1}$.

\section{Exclusion and incompatibility}

The plasmids $\mathrm{R}_{26}$ and $\mathrm{R}_{527}$ were assigned to the P-incompatibility group by their exclusion and incompatibility responses with the previously described P-group plasmid, R75I (Jobanputra \& Datta, 1974). R26 and R527 were used as the superinfecting or resident 
Table 4. Exclusion and incompatibility responses of $P$ plasmids in E. coli $\mathrm{KI} 2$

For broth matings $\left(45 \mathrm{~min}\right.$ at $37^{\circ} \mathrm{C}$ ), equal volumes of donor and recipient bacteria at $5 \times 10^{8}$ bacteria/ml were used. Donors were $R^{+}$lines of UBI30I and recipients were JC3272 and its $R^{+}$ derivatives. Selection was on supplemented $\mathrm{MM}$ using $\mathrm{Cb}\left(250 \mu \mathrm{g} \mathrm{ml}^{-1}\right)$ and $\mathrm{Tp}\left(60 \mu \mathrm{g} \mathrm{ml}^{-1}\right)$ as appropriate. Streptomycin $\left(250 \mu \mathrm{g} \mathrm{m}^{-1}\right)$ was used for counter selection.

\begin{tabular}{|c|c|c|c|c|}
\hline Donor & Recipient & $\begin{array}{l}\text { Selected } \\
\text { marker }\end{array}$ & $\begin{array}{l}\text { Frequency of } \\
\text { resistant } \\
\text { transcipients/ } \\
\text { donor cell }\end{array}$ & $\begin{array}{l}\text { Phenotype of } \\
\text { transcipients }\end{array}$ \\
\hline $\begin{array}{l}R_{75} I \\
R_{751} \\
R_{751} \\
R 75 I\end{array}$ & $\begin{array}{l}\mathrm{R}^{-} \\
\text {RPI } \\
\text { R26 } \\
\text { R527 }\end{array}$ & $\begin{array}{l}\text { Tp } \\
\text { Tp } \\
\text { Tp } \\
\text { Tp }\end{array}$ & $\begin{array}{l}8 \cdot 1 \times 10^{-4} \\
5 \cdot 1 \times 10^{-6} \\
5 \cdot 2 \times 10^{-6} \\
6 \cdot 9 \times 10^{-6}\end{array}$ & $\begin{array}{l}\text { 40/40 Tp-r Cb-s } \\
\text { 40/40 Tp-r Cb-s } \\
\text { 35/35 Tp-r Cb-s }\end{array}$ \\
\hline $\begin{array}{l}\text { RPI } \\
\text { RPI }\end{array}$ & $\begin{array}{l}\mathrm{R}^{-} \\
\mathrm{R}_{75 \mathrm{I}}\end{array}$ & $\begin{array}{l}\mathrm{Cb} \\
\mathrm{Cb}\end{array}$ & $\begin{array}{l}2.6 \times 10^{-3} \\
1 \cdot 4 \times 10^{-4}\end{array}$ & $20 / 20 \overline{\mathrm{Cb}-\mathrm{r} T \mathrm{~T}-\mathrm{s}}$ \\
\hline $\begin{array}{l}\text { R26 } \\
\text { R26 }\end{array}$ & $\begin{array}{l}\mathbf{R}^{-} \\
\mathbf{R}_{751}\end{array}$ & $\begin{array}{l}\mathrm{Cb} \\
\mathrm{Cb}\end{array}$ & $\begin{array}{l}3.6 \times 10^{-5} \\
1.5 \times 10^{-6}\end{array}$ & $32 / 40$ Cb-r Tp-s \\
\hline $\begin{array}{l}\text { R527 } \\
\text { R527 }\end{array}$ & $\begin{array}{l}\mathbf{R}^{-} \\
\mathbf{R}_{75} \mathrm{I}\end{array}$ & $\begin{array}{l}\mathrm{Cb} \\
\mathrm{Cb}\end{array}$ & $\begin{array}{l}2.4 \times 10^{-3} \\
0.8 \times 10^{-4}\end{array}$ & 20/20 Cb-r Tp-s \\
\hline
\end{tabular}

plasmids in a series of reciprocal matings with bacteria harbouring R75 I. Similar experiments using $\mathrm{RP}_{1}^{+}$and $\mathrm{R}_{75 \mathrm{I}^{+}}$bacteria were included as controls (Table 4). Exclusion was evident in each of these pairwise matings since the inheritance of R75I, as indicated by the recovery of Tp-r transcipients, was reduced 100-fold by bacteria harbouring RPI, R26 or R527 and, conversely, the inheritance of these three plasmids was reduced 20 -fold by bacteria harbouring R75I.

The compatibility properties of the superinfecting and resident plasmids were determined from the resistance phenotypes of the $\mathrm{Cb}-\mathrm{r}$ and $\mathrm{T} p-\mathrm{r}$ transcipients recovered. In almost every case the resident plasmid had been displaced by the superinfecting one, indicating that $\mathrm{R}_{75} \mathrm{I}$ was incompatible with $\mathrm{RPI}, \mathrm{R}_{26}$ and $\mathrm{R}_{527}$ and hence that all four plasmids were members of the P group. Although the resistance phenotypes of $\mathrm{R}_{26} 6$ and $\mathrm{R} 527$ precluded the formal demonstration of incompatibility between these plasmids or between them and RPI, exclusion by bacteria harbouring the latter could be demonstrated (data not shown). It seems likely, therefore, that matings involving all combinations of these plasmids would give similar results to those obtained with $\mathrm{R}_{75} \mathrm{I}$.

\section{Properties of P-group plasmids}

To determine the similarity between the various P-group plasmids, the properties they confer were compared with those determined by RPI. Table 5 summarizes the results.

Host range of male-specific phages. $\mathrm{RP}_{\mathrm{I}}+$ bacteria are hosts for three types of male-specific phages: the RNA phage PRRI (Olsen \& Thomas, 1973), the double-stranded DNA phages PRDI, PR 3 and PR4 (Olsen et al., 1974; Bradley, 1974; Stanisich, 1974 $b$; Bradley \& Rutherford, 1975), and the filamentous phage Pf3 (Bradley, 1974; Stanisich, 1974b). The double-stranded DNA phages can infect bacteria harbouring plasmids of incompatibility groups other than P (Olsen et al., I974; Kontomichalou \& Papachristou, 1975; Bradley \& Rutherford, 1975), but so far this broad host range has not been found for PRR I or Pf3. Table 5 shows the plating efficiencies of these phages on various $\mathrm{R}^{+}$lines of $E$. coli KI2 compared with those obtained on $P$. aeruginosa PAO harbouring RPI.

Of the two bacterial species, $P$. aeruginosa was the more suitable as high plating 
Table 5. Phenotypic properties of P plasmids in P. aeruginosa $\mathrm{PAO}$ and E. coli $\mathrm{KI} 2$

\begin{tabular}{|c|c|c|c|c|c|c|c|c|c|c|c|}
\hline \multirow[b]{3}{*}{ Plasmid } & \multicolumn{7}{|c|}{ Efficiency of plating* } & \multirow{3}{*}{$\begin{array}{c}\text { Plasmid } \\
\text { transfer } \\
\text { to } \mathrm{B}_{3} \\
\text { lysogen§ }\end{array}$} & \multirow{3}{*}{$\begin{array}{c}\text { Response of } \\
\mathrm{P}^{+} \text {bacteria to } \\
\text { aeruginocin } \\
\text { AP4I } \|\end{array}$} & \multirow{2}{*}{\multicolumn{2}{|c|}{$\begin{array}{c}\text { Fertility } \\
\text { inhibition } \\
\text { of } \\
\text { P plasmid } \\
\text { by } \Upsilon \text { f }\end{array}$}} \\
\hline & \multicolumn{5}{|c|}{ Male-specific phage $\dagger$} & \multicolumn{2}{|c|}{$\begin{array}{l}\text { Female- } \\
\text { specific } \\
\text { phage } \ddagger\end{array}$} & & & & \\
\hline & PRRI & $\mathrm{PR}_{3}$ & $\mathrm{PR}_{4}$ & PRDI & $\mathrm{Pf}_{3}$ & Gror & GIOI-I & & & $\mathrm{R}_{3} 8$ & $\mathrm{R}_{38-5}$ \\
\hline RPI & $10^{-3}$ & $\left(10^{-5}\right)$ & $10^{-1}$ & $10^{-1}$ & $\left(10^{-6}\right)$ & $10^{-4}$ & I & $10^{-4}$ & $\mathbf{R}$ & + & - \\
\hline R26 & $10^{-3}$ & $\left(10^{-5}\right)$ & $10^{-1}$ & $10^{-1}$ & $\left(10^{-6}\right)$ & $10^{-4}$ & I & $10^{-4}$ & $\mathbf{R}$ & + & - \\
\hline R527 & $1 \mathrm{O}^{-3}$ & $\left(10^{-5}\right)$ & $10^{-1}$ & $10^{-1}$ & $\left(10^{-6}\right)$ & $10^{-4}$ & I & $10^{-4}$ & $\mathbf{R}$ & + & - \\
\hline R906 & $10^{-3}$ & $<10^{-6}$ & $10^{-1}$ & $10^{-1}$ & $\left(10^{-6}\right)$ & $10^{-4}$ & I & $10^{-3}$ & $\mathbf{S}$ & + & - \\
\hline R75I & $\left(10^{-7}\right)$ & $<\mathrm{IO}^{-6}$ & $\left(10^{-6}\right)$ & $\left(10^{-6}\right)$ & $\left(\mathrm{IO}^{-7}\right)$ & $10^{-4}$ & I & $10^{-8}$ & $\tilde{S}$ & + & - \\
\hline
\end{tabular}

* Efficiencies of plating were determined by spot assays. Parentheses indicate that complete lysis of the bacterial lawn occurred at the e.o.p. shown but that single plaques were not formed at lower dilutions.

$\dagger$ Efficiencies of plating are relative to those on $P$. aeruginosa $\mathrm{RPI}^{+}$. The data shown are responses using $\mathrm{P}^{+}$sub-lines of $E$. coli Jc3272. Efficiencies of plating using $\mathrm{P}^{+}$lines of $P$. aeruginosa $\mathrm{PA02635}$ were all $\mathrm{I} \cdot 0$.

$\ddagger$ Efficiencies of plating were determined using $\mathrm{P}^{+}$lines of $P$. aeruginosa PA08, and are relative to those obtained on PA08.

$\S$ Transfer frequencies to $P$. aeruginosa PA09502 are relative to those obtained with PA0950I. Donors were derivatives of PAO2635. Matings were for $\mathrm{I} h$ using equal volumes of parental bacteria (about $5 \times 10^{8}$ bacteria/ml) in NB. Selection was on NA supplemented with $\mathrm{Cb}\left(250 \mu \mathrm{g} \mathrm{ml}^{-1}\right)$ or $\mathrm{Hg}\left(18 \mu \mathrm{g} \mathrm{ml}^{-1}\right)$, or on MM supplemented with Tp (I mg ml-1). Rifampicin (I50 $\mu \mathrm{g} \mathrm{ml}^{-1}$ ) was used for counterselection.

\|I Sensitivity (S) or insensitivity (R) to AP4I was determined using $\mathrm{P}^{+}$sub-lines of $P$. aeruginosa $\mathrm{PA09502}$ and aeruginocin of titre 8-16.

T Bacteria harbouring the P-group plasmids together with $\mathrm{R}_{3} 8$ or $\mathrm{R}_{3} 8-5$ were constructed in $P$. aeruginosa PAO2635. Fertility inhibition of the P plasmid $(+)$ was detected by resistance of the strain to phages PRR I and $\mathrm{Pf}_{3}$, and by decreased transferability of the P plasmid in matings with PAO2637.

efficiencies were obtained for all the phages on the $\mathrm{R}^{+}$sub-lines used. In contrast, the plating efficiencies on $E$. coli hosts varied widely, and although lysis could generally be detected using high titres of phage, plaque formation was often absent. The possibility that a correlation existed between the frequency of plasmid transfer and the efficiency of phage plating was examined, but none was found. Thus, transfer frequencies using $P$. aeruginosa donors ranged from $\mathrm{I} \cdot \mathrm{O} \times 1 \mathrm{IO}^{-2}$ to $2 \cdot \mathrm{I} \times 10^{-3}$ /donor during $30 \mathrm{~min}$ mating (selecting $\mathrm{Cb}-\mathrm{r}$, $\mathrm{Tp}-\mathrm{r}$ or $\mathrm{Hg}-\mathrm{r}$ transcipients as appropriate) whereas with $E$. coli they were about Io times lower $\left(\mathrm{I}^{\circ} 5 \times 1 \mathrm{IO}^{-3}\right.$ to $\left.6.3 \times 10^{-5}\right)$. However, despite the wide differences in plating efficiencies, the host range of both PRRI and Pf 3 extended to $\mathrm{P}^{+}$hosts other than those harbouring $\mathrm{RPI}$, and could be detected in both $P$. aeruginosa and $E$. coli.

Plating efficiencies of female-specific phages. The presence of RPI in P. aeruginosa PAO reduces the plating of the temperate phage Gror by about $10^{-4}$ (Krishnapillai, 1974) and a similar reduction was found with bacteria harbouring R26, R527, R75I and R906 (Table 5). In contrast, phages B33, B39, E79 and FI I6L which show interactions with other Pseudomonas R plasmids (Krishnapillai, 1974; Morgan \& Stanisich, 1976) were not affected by the P-group plasmids (data not shown). The mutant phage GIoI-I was used to distinguish the specificity of the inhibition mediated by the P-group plasmids from that which occurs with R9I. This plasmid is compatible with RPI and mutants of it which are derepressed for transfer function interfere with the plating of both GIOI and GIOI-I (e.o.p., IO ${ }^{-4}$; Chandler, I975). However, GIOI-I is not susceptible to inhibition by RPI, nor was this observed with any of the other P-group plasmids. Since the sensitivity of $\mathbf{P}^{+}$ bacteria to infection by the plasmid-specific phage PRRI suggests that they are derepressed for transfer function, it was concluded that the specificity of the interaction between GIOI and the plasmids R26, R527, R75I and R906 was similar to that mediated by RPI. 
Interaction with prophage $\mathrm{B}_{3}$. The presence of prophage $\mathrm{B}_{3}$ in $P$. aeruginosa $\mathrm{PAO}$ reduces the bacteria's inheritance of the RPI-like plasmid RI8-3 (Krishnapillai, 1975). A reduction of about $10^{-3}$ was found in the recovery of all the P-group plasmids when matings involved B3 lysogenic recipients rather than non-lysogens. This suggests that the interaction between $\mathrm{B}_{3}$ and plasmids of the $\mathbf{P}$ group is a general one.

Insensitivity to aeruginocin $\mathrm{AP}_{4} \mathrm{I}$. P. aeruginosa 4I produces an aeruginocin, $\mathrm{AP}_{4} \mathrm{I}$, which is lethal to P. aeruginosa PAO (Holloway et al., 1974). However, sub-lines harbouring RI8, a plasmid identical to RPI (Stanisich et al., 1976) can tolerate it (Chandler, 1975). Bacteria harbouring RPI, R26 and $\mathrm{R}_{527}$ were found to be insensitive to AP4I whereas those with $R_{75} I$ and $R 906$ were as sensitive as the $R^{-}$strain (Table 5). Whether RPI, R26 and R527 conferred resistance or tolerance to the aeruginocin was not examined.

Fertility inhibition. The plasmid $\mathrm{R}_{3} 8$ is compatible with RPI but inhibits its fertility when in the same cell (Stanisich, $1974 b$ ). $\mathrm{R}_{38} 8^{+} \mathrm{RPI}_{\mathrm{I}}{ }^{+}$bacteria therefore show a reduction both in sensitivity to male-specific phages and in the conjugal transfer of RPI. R38-5 is a mutant of $\mathrm{R}_{3} 8$ which has no effect on the fertility of RPI (Stanisich, unpublished data). Bacteria carrying $\mathrm{R}_{3} 8$ or $\mathrm{R}_{38-5}$ together with any of the plasmids $\mathrm{R}_{26}$, R $527, \mathrm{R}_{75} \mathrm{I}$ or R906 were found to have the same phenotypes as did those with RPI (Table 5). R38 therefore seems to inhibit the fertility of each of these P-group plasmids by a similar mechanism.

With the exception of response to aeruginocin, the various P-group plasmids conferred similar or identical phenotypes for the range of characteristics studied, and it was concluded that these plasmids have several genes in common. The possible origin of these genes and their distribution on the plasmid molecule is discussed below.

\section{Transduction and marker rescue}

RPI has a molecular weight of $38 \times 10^{6}$ daltons and is transducible by FiI6L which has a genome of $40 \times 10^{6}$ daltons (Stanisich \& Richmond, I975). Attempts to transduce R26 and R527 with FII6L were unsuccessful indicating that these plasmids were larger than RPI. Since the preceding data suggested a similarity between RPI, R26 and R527, the transduction experiments were repeated using recipients carrying $\mathrm{R} I 8-\mathrm{I} 8$, a $\mathrm{Cb}$-s derivative of R I8. Cb-r and $\mathrm{Hg}-\mathrm{r}$ transductants could then be recovered at frequencies that were 5 to 10 times lower than when selection was for the chromosomal allele $\arg 32^{+}$, or a plasmid marker (Cb-r) from RPI (Table 6, lines I and 2).

Table 7 shows the phenotypes of the transductants obtained in a similar experiment in which the recipient carried $\mathrm{R} I$ 8-9I, a transfer-defective derivative of $\mathrm{R}_{\mathrm{I}}$ 8-18. Linkage of the resistance determinants $\mathrm{Cb} \mathrm{Sm} \mathrm{Su} \mathrm{Gm} \mathrm{Hg}$ is seen in their coinheritance by 80 to $90 \%$ of the $\mathrm{Cb}-\mathrm{r}$ and $\mathrm{Hg}-\mathrm{r}$ transductants. Furthermore, the determinants $\mathrm{Sm} \mathrm{Su} \mathrm{Gm} \mathrm{Hg}$ are more closely linked to each other than to $\mathrm{Cb}$ since these may be inherited independently of $\mathrm{Cb}$ but not of each other. These five determinants are also coinherited with transfer function suggesting that both $\mathrm{R}_{26} 6$ and $\mathrm{R}_{527}$ are composite plasmids in which the sex factor is continuous with the resistance genes.

To determine the mechanism by which markers from $\mathrm{R}_{26} 6$ and $\mathrm{R}_{527}$ survived in Ri8-i 8 bacteria, transduction experiments were carried out using the recombinationdeficient strain PAO2002 (Chandler \& Krishnapillai, I974a). Transduction of RPI occurred to both PAO2002 and its RI 8-I 8 derivative, whereas transduction of R26 or R527 could not be detected to either strain (Table 6 , lines 3 and 4 ). Thus while marker rescue in $\mathrm{R}$ I8-I $8^{+}$ $\mathrm{Rec}^{-}$hosts indicates that $\mathrm{F}_{11} \mathrm{LL}$ can transduce portions of $\mathrm{R}_{26} 6$ and $\mathrm{R}_{52}$, the survival of such fragments in the new host is clearly dependent on the presence both of RI8-I 8 and of a functional host recombination system. Despite the low frequency of transduction, it 
Table 6. Transduction of plasmids RPI and R26 to Rec ${ }^{+}$and $\mathrm{Rec}^{-}$lines of

$$
P \text {. aeruginosa PAO }
$$

The recipients were PAO200I, its $\mathrm{Rec}^{-}$derivative PAO2002, and their $\mathrm{R}_{1} 8$ - 18 sub-lines. Transducing preparations of phage FI I 6L were from $\mathrm{P}^{+}$sub-lines of PAO950I. Phage-bacterial mixtures (multiplicity of infection, m.o.i. 10 to 20 ) were maintained at $37^{\circ} \mathrm{C}$ for $45 \mathrm{~min}$ : the cells were then concentrated about Io-fold and $0.1 \mathrm{ml}$ samples plated on selective medium. Selection for $\mathrm{Arg}^{+}$ transductants was on $\mathrm{MM}$; selection for $\mathrm{Cb}-\mathrm{r}$ and $\mathrm{Hg}-\mathrm{r}$ transductants was on NA containing $\mathrm{Cb}$ $\left(250 \mu \mathrm{g} \mathrm{ml}^{-1}\right)$ and $\mathrm{Hg}\left(\mathrm{I} 8 \mu \mathrm{g} \mathrm{ml}^{-1}\right)$.

\begin{tabular}{|c|c|c|c|c|c|c|}
\hline \multirow[b]{3}{*}{ Recipient } & \multicolumn{6}{|c|}{ Transductants $/ 10^{10}$ plaque-forming units } \\
\hline & \multicolumn{3}{|c|}{ FII6L.RPI } & \multicolumn{3}{|c|}{$\mathrm{FI}_{16 . R 26 *}$} \\
\hline & $\mathrm{Arg}^{+}$ & $\mathrm{Cb}-\mathrm{r}$ & $\mathrm{Hg}-\mathrm{r}$ & $\mathrm{Arg}^{+}$ & Cb-r & Hg-r \\
\hline $\operatorname{Rec}^{+}$ & IOI & 54 & 0 & 130 & 0 & 0 \\
\hline $\operatorname{Rec}^{+}$. RI 8-I 8 & 103 & 43 & 0 & 131 & I I & 27 \\
\hline $\operatorname{Rec}^{-}$ & 0 & 20 & 0 & 0 & 0 & 0 \\
\hline $\mathrm{Rec}^{-} \cdot \mathrm{R}_{1} 8-\mathrm{I} 8$ & 0 & 22 & 0 & 0 & 0 & 0 \\
\hline
\end{tabular}

* Similar results were obtained when phage was grown on $\mathrm{R} 527$ donors.

\section{Table 7. Analysis of $\mathrm{R} 26$ transductants from a recipient harbouring the plasmid $\mathrm{R}$ I 8-9I}

PA0950I.RI 8-9I was the recipient for phage FII6L propagated on PA08.R26. The transductional procedure was as described in Table 6 except that the m.o.i. was 5 .

\begin{tabular}{|c|c|c|c|c|c|}
\hline \multirow{2}{*}{$\begin{array}{l}\text { Selected* } \\
\text { marker }\end{array}$} & \multicolumn{4}{|c|}{ Unselected marker $\dagger$} & \multirow{2}{*}{$\begin{array}{l}\text { Percentage of } \\
\text { transductants }\end{array}$} \\
\hline & $\mathrm{Cb}$ & $\mathrm{Hg}$ & $\mathrm{Sm}, \mathrm{Su}, \mathrm{Gm}$ & Tra & \\
\hline $\mathrm{Cb}-\mathrm{r}$ & & $\begin{array}{l}\mathbf{R} \\
\mathbf{R} \\
\mathbf{S}\end{array}$ & $\begin{array}{l}\mathrm{R} \\
\mathrm{R} \\
\mathrm{S}\end{array}$ & $\begin{array}{l}+ \\
- \\
-\end{array}$ & $\begin{array}{l}19 \\
60 \\
21\end{array}$ \\
\hline Hg-r & $\begin{array}{l}\mathbf{R} \\
\mathbf{R} \\
\mathbf{S} \\
\mathbf{S}\end{array}$ & & $\begin{array}{l}\mathrm{R} \\
\mathrm{R} \\
\mathrm{R} \\
\mathrm{R}\end{array}$ & $\begin{array}{l}+ \\
+ \\
-\end{array}$ & $\begin{array}{r}38 \\
47 \\
8 \\
7\end{array}$ \\
\hline
\end{tabular}

* Numbers of transductants analysed were: Cb-r, 80; Hg-r, 120.

$\dagger \mathbf{R}$, Resistance; $\mathrm{S}$, sensitivity to the antibiotics and mercuric ions. Transfer proficiency $(+)$ or deficiency $(-)$ was determined from the response to male-specific phage $\mathrm{Pf}_{3}$.

seems fair to conclude that marker rescue involves recombination of the transduced fragment with the resident plasmid, and that sufficient homology exists between these plasmids to allow these events to occur.

\section{DISCUSSION}

One of the most striking features of P-group plasmids is their ready transfer across generic boundaries, so the derivation of the plasmids used in this study from species of Pseudomonas, Bordetella, Serratia and Klebsiella is not in itself particularly surprising (see Table 2). By a comparative study of these plasmids based primarily on phenotypic criteria, we have shown that despite their differences in resistance phenotype they share several properties in common and therefore may be derived from a single element which is becoming more widespread or is already endemic in different areas. Their gross similarity at the molecular level probably accounts for the recombination that occurs between them when determinants from R26 and $R_{527}$ are rescued by $R_{18}$. Recombination is implicated in this process because 
transductants are recovered only from $\mathrm{Rec}^{+}$recipients (Table 6), but direct evidence has been obtained in a separate study (Stanisich et al., 1976) in which the sizes of the plasmids carried by these transductants has been determined.

Most of the characteristics common to the P-group plasmids are those which might be expected to be controlled by genes on the transfer factor: for example, interaction with sexspecific phages and inhibition by $\mathrm{R}_{3} 8$. However, only those plasmids with the resistance pattern $\mathrm{Cb} \mathrm{Nm} / \mathrm{Km} \mathrm{Tc}$ were insensitive to aeruginocin $\mathrm{AP}_{4} \mathrm{I}$, and it may be that this phenotype is controlled by a gene linked to the R-determinants. This possibility is supported by the phenotypes exhibited by recombinants between RPI and the non-transmissible plasmid pVSi. One such recombinant class retains all the characteristics of pVSr but has acquired, presumably in a single event, resistance to both carbenicillin and AP4I (Stanisich, 1974a; Stanisich, unpublished data). This implies close linkage between these two resistance determinants.

In addition to P-group plasmids, other drug-resistance plasmids occur in $P$. aeruginosa (Stanisich, 1976). These can confer resistance to $\mathrm{Sm}$ in combination with $\mathrm{Su}, \mathrm{Gm}$ and $\mathrm{Hg}$ (Bryan et al., 1973), and include plasmids like R38 which can inhibit the fertility of RPI and recombine with it (Jacoby, 1974; Stanisich, unpublished data). The phenotypic similarity between RPI, R26 and R527 therefore introduces the possibility that the last two may represent the emergence, in the clinical situation, of recombinants between an RPI-like element and another which contributes the additional resistance determinants. The finding that the $\mathrm{Sm} \mathrm{Su} \mathrm{Gm} \mathrm{Hg}$ determinants of $\mathrm{R}_{26} 6$ are encoded in a DNA fragment of molecular weight $14 \times 10^{6}$ daltons supports this view, since $R_{26}$ and $R_{527}\left(52 \times 10^{6}\right.$ daltons) and RPI ( $38 \times 10^{6}$ daltons) differ by a molecule of this size (Stanisich et al., 1976). Thus, although most Pseudomonas plasmids are not readily transferable to Escherichia, the ability of the P-group plasmids to achieve this endows them with the potential to acquire new combinations of genetic information and to transmit it to these and other organisms. The biological and clinical implications of this have not yet been assessed.

The generous provision of bacterial strains and phages is gratefully acknowledged. We thank Drs P. M. Chandler and V. Krishnapillai for discussion of their results prior to publication. J.M.O. is grateful to Professor M. H. Richmond for the hospitality of his laboratory. Financial support for this work was from a Medical Research Council grant to M. H. Richmond.

\section{REFERENCES}

Achtman, M., Willetts, N. \& Clark, A. J. (I971). Beginning a genetic analysis of conjugational transfer determined by the $\mathrm{F}$ factor in Escherichia coli by isolation and characterisation of transfer-deficient mutants. Journal of Bacteriology ro6, 529-538.

Beard, J. P., Howe, T. G. B. \& Richmond, M. H. (1972). Purification of sex pili from Escherichia coli carrying a derepressed F-like R factor. Journal of Bacteriology 111, 814-820.

BraDley, D. E. (1974). Adsorption of bacteriophages specific for Pseudomonas aeruginosa R factors RPI and R1822. Biochemical and Biophysical Research Communications 57, 893-900.

Bradley, D. E. \& Rutherford, E. L. (I975). Basic characterisation of a lipid-containing bacteriophage specific for plasmids of the $\mathrm{P}, \mathrm{N}$, and $\mathrm{W}$ compatibility groups. Canadian Journal of Microbiology $\mathbf{2 1}$, $152-163$.

Bryan, L. E., Semaka, S. D., van den Elzen, H. M., Kinnear, J. E. \& Whitehouse, R. L. S. (I973). Characteristics of R931 and other Pseudomonas aeruginosa R factors. Antibiotic Agents and Chemotherapy 3, 625-637.

Chander, P. M. (1975). Genetic properties of $R$ factors of Pseudomonas aeruginosa. Ph.D. thesis, Monash University, Australia.

Chandler, P. M. \& Krishnapillat, V. (1974a). Isolation and properties of recombination deficient mutants of Pseudomonas aeruginosa. Mutation Research 23, 15-23. 
Chandler, P. M. \& Krishnapillai, V. (1974b). Phenotypic properties of R factors of Pseudomonas aeruginosa: $\mathrm{R}$ factors readily transferable between Pseudomonas and Enterobacteriaceae. Genetical Research 23, 239-250.

Datta, N., Hedges, R. W., Shaw, E. J., Sykes, R. B. \& Richmond, M. H. (I971). Properties of an R factor from Pseudomonas aeruginosa. Journal of Bacteriology ro8, I244-I 249.

Davey, R. B. \& PitTaRd, A. J. (I974). Genetic and biophysical study of R plasmids conferring sulphonamide resistance in Shigella strains isolated in 1952 and 1956. Journal of Bacteriology 120, I I 86-1 195.

Grant, A. \& PITTARD, A. J. (I974). Incompatibility reactions of R plasmids isolated from Escherichia coli of animal origin. Journal of Bacteriology 120, $185-1$ go.

Grinsted, J., Saunders, J. R., Ingram, L. C., Sykes, R. B. \& Richmond, M. H. (1972). Properties of an $\mathrm{R}$ factor which originated in Pseudomonas aeruginosa 1 822. Journal of Bacteriology 110, 529-537.

Hedges, R. W., JAcoB, A. \& Smith, J. T. (1974). Properties of an R factor from Bordetella bronchiseptica. Journal of General Microbiology 84, I99-204.

Hedges, R. W., Rodriguez-Lemoine, V. \& DATTA, N. (1975). R factors from Serratia marcescens. Journal of General Microbiology 86, 88-92.

Holloway, B. W. \& Krishnapillai, V. (1975). Bacteriophages and bacteriocins of Pseudomonas. In Genetics and Biochemistry of Pseudomonas, pp. 92-132. Edited by P. H. Clarke and M. H. Richmond. London: Wiley.

Holloway, B. W. \& Richmond, M. H. (I973). R factors used for genetic studies in strains of Pseudomonas aeruginosa and their origin. Genetical Research 2I, 103-105.

Holloway, B. W., Rossiter, H., Burgess, D. \& DodGe, J. (1974). Aeruginocin tolerant mutants of Pseudomonas aeruginosa. Genetical Research 22, 239-253.

IsaAC, J. H. \& Holloway, B. W. (I968). Control of pyrimidine biosynthesis in Pseudomonas aeruginosa. Journal of Bacteriology 96, I732-1741.

JACOBY, G. A. (1974). Properties of $\mathbf{R}$ plasmids determining gentamicin resistance by acetylation in Pseudomonas aeruginosa. Antimicrobial Agents and Chemotherapy 6, 239-252.

Jobanputra, R. S. \& DatTa, N. (1974). Trimethoprim R factors in Enterobacteria from clinical specimens. Journal of Medical Microbiology 7, I69-1 77.

Kontomichalou, P. \& Papachristou, E. (1975). Multiresistance plasmids in Pseudomonas aeruginosa highly resistant to gentamicin. International Symposium on Microbial Drug Resistance, Tokyo, 1974. Edited by S. Mitsuhashi and $\mathbf{H}$ Hashimoto. Tokyo: University Press.

KRISHNAPILLAI, V. (1974). The use of bacteriophages for differentiating plasmids of Pseudomonas aeruginosa. Genetical Research 23, 327-334.

KRISHNAPILlAI, V. (1975). Interaction between a prophage and R factors in Pseudomonas aeruginosa. Proceedings of the Society for General Microbiology 3, 54.

Morgan, T. M. \& Stanisich, V. A. (I976). Properties of phage B33: a female-specific bacteriophage of Pseudomonas aeruginosa. Journal of General Virology 30, 73-79.

OlsEN, R. H., SiaK, J. S. \& GRAY, R. H. (I974). Characteristics of PRDi, a plasmid-dependent broad host range DNA bacteriophage. Journal of Virology 14, 689-699.

Olsen, R. H. \& Thomas, D. A. (I973). Characteristics and purification of PRRI, an RNA phage specific for the broad host range Pseudomonas RI 822 drug resistance plasmid. Journal of Virology 12, I 560-I 567.

Stanisich, V. A. (1974a). Interaction between an $\mathrm{R}$ factor and an element conferring resistance to mercuric ions in Pseudomonas aeruginosa. Molecular and General Genetics 128, 201-212.

Stanisich, V. A. (1974b). Properties and host range of male-specific bacteriophages of Pseudomonas aeruginosa. Journal of General Microbiology 84, 332-342.

Stanisich, V. A. (1976). Isolation and characterisation of plasmids in Pseudomonas aeruginosa. Bulletin de l'Institut Pasteur (in the Press).

Stanisich, V. A., Bennetr, P. M. \& Ortiz, J. M. (I976). A molecular analysis of transductional marker rescue involving P-group plasmids in Pseudomonas aeruginosa. Molecular and General Genetics $\mathbf{1 4 3}$, 333-337.

Stanisich, V. A. \& Holloway, B. W. (1972). A mutant sex factor of Pseudomonas aeruginosa. Genetical Research 19, 91-108.

Stanisich, V. A. \& Richmond. M. H. (1975). Gene transfer in the genus Pseudomonas. In Genetics and Biochemistry of Pseudomonas, pp. 163-190. Edited by P. H. Clarke and M. H. Richmond. London: wiley. 